Canadian Journal of Bioethics

c. S Canadian Journal of Bioethics

Revue canadienne de bioéthique

\title{
Book Review: What time is the 9:20 bus? A Journey to a Meaningful Life, Disability and All, by Lucinda Hage (2014)
}

\section{Aedan Garcia}

Volume 2, Number 2, 2019

URI: https://id.erudit.org/iderudit/1058144ar

DOI: https://doi.org/10.7202/1058144ar

See table of contents

Publisher(s)

Programmes de bioéthique, École de santé publique de l'Université de Montréal

ISSN

2561-4665 (digital)

Explore this journal

Cite this article

Garcia, A. (2019). Book Review: What time is the 9:20 bus? A Journey to a Meaningful Life, Disability and All, by Lucinda Hage (2014). Canadian Journal of Bioethics / Revue canadienne de bioéthique, 2(2), 19-20.

https://doi.org/10.7202/1058144ar
Article abstract

This book review considers the challenges of raising a child with a developmental disability as seen in the book What time is the $9: 20$ bus? by Lucinda Hage. Beyond being an emotional and compelling narrative of a mother struggling to navigate Canada's medical and social support systems, the book is also an excellent introduction to the fields of bioethics, disability ethics, and resource allocation ethics.
All Rights Reserved @ Aedan Garcia, 2019

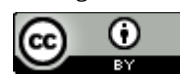

This document is protected by copyright law. Use of the services of Érudit (including reproduction) is subject to its terms and conditions, which can be viewed online.

https://apropos.erudit.org/en/users/policy-on-use/ 


\section{Book Review: What time is the 9:20 bus? A Journey to a Meaningful Life, Disability and All, by Lucinda Hage (2014)}

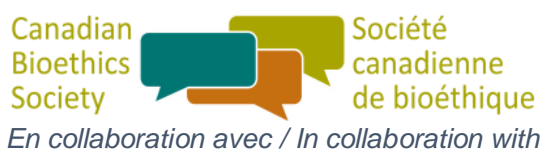

Aedan Garcia ${ }^{1}$

Résumé

Ce compte rendu examine les défis de l'éducation d'un enfant ayant une déficience intellectuelle telle que vue dans le livre What time is the 9:20 bus? de Lucinda Hage. En plus d'être le récit émouvant et convaincant d'une mère qui lutte pour naviguer à travers les systèmes de soutien médical et social du Canada, le livre est aussi une excellente introduction aux domaines de la bioéthique, de l'éthique du handicap et de l'allocation des ressources.

Mots-clés

This book review considers the challenges of raising a child with a developmental disability as seen in the book What time is the 9:20 bus? by Lucinda Hage. Beyond being an emotional and compelling narrative of a mother struggling to navigate Canada's medical and social support systems, the book is also an excellent introduction to the fields of bioethics, disability ethics, and resource allocation ethics.

bioéthique, éthique du handicap, allocation des ressources, soutien communautaire, services résidentiels

\section{Keywords}

bioethics, disability ethics, resource allocation, community support, residential services

What time is the 9:20 bus? [1] is an account of a mother, Lucinda Hage, raising her son, Paul, who has a rare neurological disorder called tuberous sclerosis complex (TSC). Beyond the book being an emotional and compelling narrative of a mother struggling to navigate Canada's medical and social support systems, it is also an excellent introduction to the fields of bioethics, disability ethics, and resource allocation ethics. Overall, the book shows the immense difficulties that children with disabilities face in hospitals, schools, social programs, and in sustaining independent living strategies. The book is also very much about the emotional and social impact of raising a child with a developmental disability. ${ }^{1}$

The book is broken up into four parts. In part I, Lucinda and her husband John make the decision to adopt a baby (Paul). Soon thereafter, it was discovered that Paul had TSC, which brings challenges for Lucinda as she realizes that her son will likely fall behind other children in his neurological development. Due to the stress of raising a child who constantly suffered from seizures, in addition to the collapse of Lucinda's social life and relationships, the common theme of chaos arises. In parts 2 through 4, Paul enters his high school years and the book centres on the theme of recovery. Lucinda remarries a man named Murray (after her initial marriage to John ended). The marriage brings stability and more support for Paul and this affords Lucinda a novelty in her life: free time. The themes of opportunity and community arise as well. At this time, Lucinda begins to consider, what will Paul do after he graduates? In response to this question she forms a support circle consisting of people who wanted to help Paul. When they convene, they discuss strategies to help Paul attain two main goals: 1) find him a fulfilling job and 2) find him housing so he can live independently. For employment, the support circle considers Paul's passions. Since he was young, Paul had a love for vacuums, motors, and lawn mowers. With some help he was provided the opportunity to work as a housekeeper at the Holiday Inn. Following these events, Paul was put into contact with another boy with a developmental disability. A living accord was made between the two and they would split living expenses and rent an apartment. The plan worked and Lucinda let go, not just of Paul but of two decades of hardships and triumphs. From that point onwards, Paul lived alone. Although he encountered some hurdles, Paul managed to adjust to living independently and completed a transformation that defied the odds.

The book brings to attention many realities surrounding family life when a child has a developmental disability. In her book, Lucinda seems to spare no detail, of both successes and setbacks, when speaking about the pressures that families face in these scenarios. In relation to bioethics, disability ethics, and the ethics of resource allocation, What time is the 9:20 bus? speaks to the issue of a society-wide focus on solely helping young children with disabilities, and as a result, neglecting them as adults. It is mentioned that there are many resources, institutions, government funds, and charities that help children with disabilities, however, these resources dwindle as children enter the adult world.

In the childhood of Paul, the book shows that children with developmental disabilities are often treated solely through a medical lens that attempts to address their disability with the use of prescription drugs and other treatments, but their social well-being is often missed. In this light, one major theme to be drawn from this work is that we must treat the person, not the disability. At many points, the book mentions the massive amount of prescription drugs that Paul is given, mostly to control his seizures. However, Lucinda notes that Paul made his greatest improvements when he was given the opportunity to make friends and develop social connections beyond his parents (although, medication was necessary to allow him to get to this point). He made further progress as he grew older and was employed by the YMCA Camp Wanakita and eventually the Holiday Inn. In these places, Paul did not just make friends; he learned social etiquette and how to meaningfully contribute to society. It was at these various points that Paul grew more aware of the world around him and was able to find his place. This is one of the major reasons why Paul's story is a success story.

\footnotetext{
1 I chose to use the term "developmental disability" when I refer to Paul because it seems to best describe his condition. In the book, the doctor explained that Paul's development will likely be delayed. To give better context, the doctor who diagnosed Paul explained to Lucinda that, "Yes. His development will likely be quite delayed" [p.16]. It might also be important to add that the diagnosis was made in 1986 and there was even less of an understanding of TSC when compared to now.
} 
It cannot be stressed enough the importance of creating community and pushing institutions toward constructive change. A major theme in this work (which is important for students in the world of disability ethics), is that community needs to be created to help those with developmental disabilities. It can be challenging for many of these individuals to obtain housing and employment opportunities, and parents alone cannot overcome these many obstacles. Because people with developmental disabilities may suffer from limited social contact, support circles can help them overcome many issues. On a larger scale, community is a necessity in treating and understanding developmental disabilities. It is mentioned in the book that in 1996, Lucinda organized the Tuberous Sclerosis Medical Education conference in which "over 200 parents and medical personnel rubbed shoulders" [p.58]. This conference and the ones that followed contributed to a better understanding of strategies to more effectively address Paul's (and other children's') developmental disability. This is especially important because some disabilities are less common than others, and symptoms and challenges can differ greatly. Advocacy within communities can also improve government allocation of funds. In the book, Lucinda mentions that the amount of funding available was usually not an issue, given that the Ontario government contributed 1.7 billion dollars into a developmental and residential services fund in the 2011-2012 fiscal years. However, the book also makes note of the fact that there were still 13,000 people on a waiting list to access these funds [p.169]. This goes to show that one of the biggest challenges is not a lack of funding, but rather the allocation of the funds. An example of addressing this problem is provided in the book.

Despite the praise for this book, there is one major detail that must be noted. It is clear that Paul's success story was dependent on the almost super human ability and stamina of Lucinda, his mother; and this means that Paul's success was circumstantial. Without her, Paul's likelihood of success would likely have be diminished, as not every child with a disability has a mother or father with the will, power, and drive to follow through with ideas, to not be hindered by rejection, and to have the financial stability that allowed Paul's mother to take time off work to help him. This may speak to the broader point of creating a better system to distribute resources to parents in need of such aid. In many cases where a child does not have a parent like Lucinda, or in the situation where both parents are working, how can parents properly help? In other words, it must be noted that not all parents display the same incredible characteristics as Lucinda or have similar financial circumstances. This is a vital point because if Paul's success story is to be seen in other children with developmental disabilities, we must ask, how can we help parents make this happen?

I would recommend this book to anyone new to the field of bioethics, disability ethics, and resource allocation ethics, especially undergraduate students. It highlights some of the main issues that people with developmental disabilities often encounter from childhood to their transition into adulthood, but it does so through the perspective of a mother trying to raise her child. This gives the reader a much more complete picture of the emotional consequences as well as the social implications in raising a child with a developmental disability. As I concluded the book, I pondered on the example of Paul and the long-term investment in services that are needed for children and adults with developmental disabilities; I encourage the reader to do so as well. This book inspires the aforementioned types of constructive dialogues.

\section{Remerciements}

M. Christopher Grafos m'a guidé tout au long du processus d'élaboration d'un compte rendu et a joué un rôle déterminant dans la réalisation de ce texte.

\section{Conflit d'intérêts}

Aucun à déclarer

Édition/Editors: Patrick Gogognon

\section{Affiliations}

${ }^{1}$ Harbord Collegiate Institute, Toronto

\section{Acknowledgements}

Dr. Christopher Grafos has mentored me through the process of constructing a book review and has been instrumental in bringing this book review to fruition.

Conflicts of Interest

None to declare

\section{Correspondance / Correspondence: Aedan Garcia, studymail110@gmail.com}

\section{Reçu/Received: 16 Dec 2018 Publié/Published: 12 Mar 2019}

Les éditeurs suivront les recommandations et les procédures décrites The editors follow the recommendations and procedures outlined in dans le Code of Conduct and Best Practice Guidelines for Journal the COPE Code of Conduct and Best Practice Guidelines for Journal Editors de COPE. Plus précisément, ils travaillent pour s'assurer des Editors. Specifically, the editors will work to ensure the highest ethical plus hautes normes éthiques de la publication, y compris l'identification standards of publication, including: the identification and management et la gestion des conflits d'intérêts (pour les éditeurs et pour les of conflicts of interest (for editors and for authors), the fair evaluation auteurs), la juste évaluation des manuscrits et la publication de of manuscripts, and the publication of manuscripts that meet the manuscrits qui répondent aux normes d'excellence de la revue.

journal's standards of excellence.

\section{References}

1. Hage L. What Time Is the 9:20 Bus? A Journey to A Meaningful Life, Disability and All. Inclusion for Life; 2nd ed.; 2014. 